\title{
Implant overdenture treatment using several solitary attachment systems on mandibular edentulous patients
}

\author{
Mid-Eum Park, Soo-Yeon Shin* \\ Department of Prosthodontics, College of Dentistry, Dankook University, Cheonan, Republic of Korea
}

Implant overdenture treatment using several solitary attachment systems on mandibular edentulous patients. Most patients with severe residual ridge resorption report significantly more problems adapting to their mandibular denture due to a lack of comfort, retention, stability and to the inability to chew and eat. Recent scientific studies carried out over the past decade have determined that the benefits of a mandibular implant overdenture are sufficient to get retention and stability. Therefore, overdenture with implants on the mandible and attachments are considered as a treatment of choice as a favorable treatment. In this cases, with consideration for jaw relation, level of bone loss, facial support and economic factor, edentulous patients with severe residual ridge resorption are rehabilitated by complete denture on maxilla and two-implants overdenture using several solitary attachment systems on mandible. (J Dent Rehabil Appl Sci 2015;31(3):242-52)

Key words: implant; mandibular edentulous; overdenture; attachment

\section{서론}

완전 무치악 환자에서는 전통적인 총의치를 이용한 가 철성 보철 수복과 임플란트를 이용한 고정성 보철 수복, 임플란트 피개의치를 이용한 가철성 보철 수복이 가능하 며, 이를 통해 심미와 기능을 회복시킬 수 있다. 특히 임 플란트를 이용한 무치악 환자의 치료는 기능적, 심미적, 심리적으로 만족스러운 결과가 보고되고 있다. ${ }^{1}$

무치악 환자는 치아 상실에 따른 지지골의 감소와 연 조직의 변형으로 인해 총의치의 유지력이 감소되고, 유 치악 환자에 비해 $1 / 6$ 이하로 저작 효율이 저하되어 의 치 사용에 어려움을 겪게 된다. ${ }^{2,3}$ 이를 개선하기 위해 1987년 Steenberghe 등에 의해 하악에 2개의 임플란트를 이용하여 수복하는 방법이 소개된 후, ${ }^{4}$ 이에 대한 많은

*Correspondence to: Soo-Yeon Shin

Professor, Department of Prosthodontics, College of Dentistry, Dankook University, 119, Dandae-ro, Dongnam-gu, Cheonan, 31116, Republic of Korea Tel: +82-41-550-0256, Fax: +82-41-550-1975, E-mail: syshin@dankook.ac.kr Received: June 12, 2015/Last Revision: June 15, 2015/Accepted: June 28, 2015
연구에서 좋은 임상 결과가 보고되고 있다. 임플란트 피 개의치는 보철물의 유지와 지지를 제공하며, 제한된 양 의 골에 임플란트를 식립함으로써 치조골 흡수가 감소되 어 치조골의 유지 측면에서 유리하게 작용한다. ${ }^{5}$ 또한 임 플란트 고정성 보철물에 비하여 의치상으로 점막의 부피 를 재현시켜줄 수 있으므로 심미적이며, 임플란트 식립 방향 및 분포 위치의 제한이 적고, 후방 cantilever에 가해 지는 힘에 대한 저항, 그리고 경제적인 측면에서 장점을 갖는다. ${ }^{6,7}$

어태치먼트는 크게 solitary type과 bar type으로 분류 되는데, 이 중 solitary type의 어태치먼트는 가격이 저렴 하고 위생관리 측면에서 우수하며, 변연골의 흡수 정도 나 임플란트 주위 조직 건강 등의 측면에 있어서 bar type 과 큰 차이가 없다고 보고되고 있다. ${ }^{8} \mathrm{Bar}$ type의 어태치

Copyright@ 2015 The Korean Academy of Stomatognathic Function and Occlusion. (c) It is identical to Creative Commons Non-Commercial License. 
먼트는 임플란트 간의 splinting 효과를 가질 수 있으며, solitary type에 비해 어태치먼트의 유지부 수리를 위한 내원 횟수가 상대적으로 적으나, $15 \mathrm{~mm}$ 이상의 충분한 악간 공간이 필요하고, 제작 과정이 복잡하다. ${ }^{9}$ 또한 높 은 안정성과 유지력은 대합치가 유치악인 경우 유리하 게 작용할 수 있으나, 상악이 무치악인 경우 하악 의치 의 과도한 지지와 안정으로 인한 combination syndrome 의 발생 가능성이 여러 문헌에서 보고되었다. ${ }^{10}$ 따라서 임플란트 피개의치의 성공적인 수복을 위해서 술자는 임플란트의 종류와 악간 관계 및 공간을 평가하여 적절 한 어태치먼트를 선택하여야 한다. ${ }^{11,12}$

KERATOR $^{\circledR}$ (Daekwang IDM, Seoul, Korea) 어태 치먼트는 대부분의 임플란트에서 사용이 가능하며, 임 플란트 식립 각도의 보상이 필요한 경우에는 $15^{\circ}$ angle abutment를 이용할 수도 있다. Solitary type의 어태치먼 트 중에서 최소한의 공간을 차지하여 악간 공간이 좁은 경우에도 다양하게 사용할 수 있으며, 다양한 유지력을 갖는 male cap을 사용하여 유지력을 조절할 수 있는 특 징이 있다. EZ-LOCK ${ }^{\circledR}$ (TM Dental, Busan, Korea) 어 태치먼트는 ceramic ball에 의한 유지를 이용하며, 임플 란트 식립 각도를 편측으로 $20^{\circ}$, 양측으로 $40^{\circ}$ 까지 보상 이 가능하다. 또한 안착 시 caramic ball과 housing 사이 의 $0.4 \mathrm{~mm}$ 공간이 직접 마찰을 감소시켜 지대주에 가해 지는 응력을 줄여주는 특징을 가지고 있다. Magnetic 어 태치먼트는 keeper에 부착되는 자석의 자력을 이용하여 연결하고, 자력을 이용하기 때문에 유지부의 잦은 교체 없이 장기간 사용이 가능하며 측방력으로부터 임플란트 를 보호하는 특징을 갖는다. ${ }^{13}$ 또한 magnetic 어태치먼 트는 자석의 인력이 의치를 제 위치로 유도하여 신체적 기능 저하로 수조작이 어려워 의치 탈착에 어려움을 겪 는 환자에서 사용이 가능하다. ${ }^{14}$

본 증례들은 완전 무치악 환자에게 상악은 통상적인 총의치로, 하악은 서로 다른 종류의 어태치먼트를 이용 한 임플란트 피개의치로 수복하였다.

\section{증례 보고}

첫 번째 증례는 64세 남자 환자로서 틀니를 만들고 싶 다는 주소로 본원에 내원하였다. 구강 검사와 방사선 사 진 검사에서 다수 치아의 상실 및 만성 치주염으로 인 한 전반적인 치조골 흡수가 관찰되었다(Fig. 1). 전악 발 치 후 상하악 예비인상을 채득하여 진단 모형을 제작하
여 평가하였다(Fig. 2). 상하악 잔존 치조제는 하악이 다 소 전돌된 class III 골격 관계를 나타내고 있었고, 하악 운동의 제한이나 측두하악관절 장애 증상은 보이지 않 았다. 하악의 이공 사이에는 임플란트를 식립 하기에 충 분한 양의 골이 존재하는 것을 확인할 수 있었으며, 이 외의 특이 소견은 발견되지 않았다. 임플란트 고정성 수 복이 가능하였으나, 경제적인 부담과 환자의 수술에 대 한 거부감으로, 상악은 통상적인 총의치, 하악은 임플란 트 피개의치를 계획하였다. Bar type의 어태치먼트를 고 려할 수 있었으나, 전악 발치 후 치아의 상실 기간이 상 대적으로 오래되지 않아 치조골량이 충분하여 악간 공 간이 부족한 경우에 우선적으로 선택되어질 수 있는 $\mathrm{KERATOR}^{\circledR}$ 어태치먼트를 선택하였다. 하악의 견치 부위에 임플란트를 식립 하기로 결정 후, 임시 의치를 복제하여 진단 방사선 스텐트를 제작하고 컴퓨터 단층 영상 촬영을 시행하였다. 이를 토대로 하악 양측 견치 부위에 OSSTEM TS III $\Phi 4.0 \times 10.0$ mm (OSSTEM, Seoul, Korea)의 임플란트를 식립 하였다(Fig. 3).

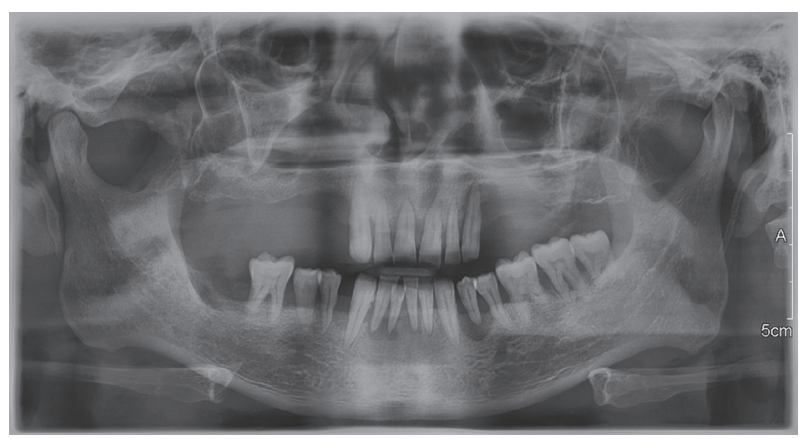

Fig. 1. Initial panoramic view of the first patients. Generalized alveolar bone loss and multiple missing of teeth state are found.

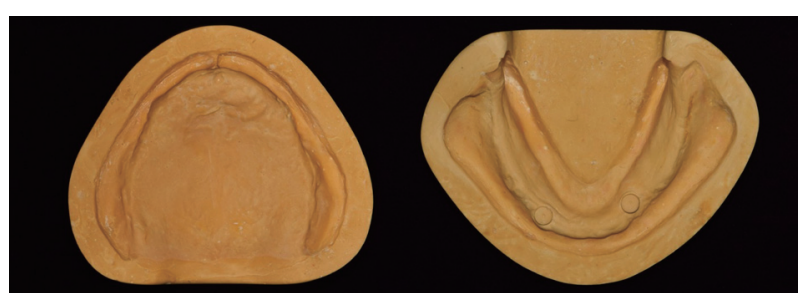

Fig. 2. Diagnostic casts of first patient. Implant installation with healing abutments was found on both mandibular canine area. 


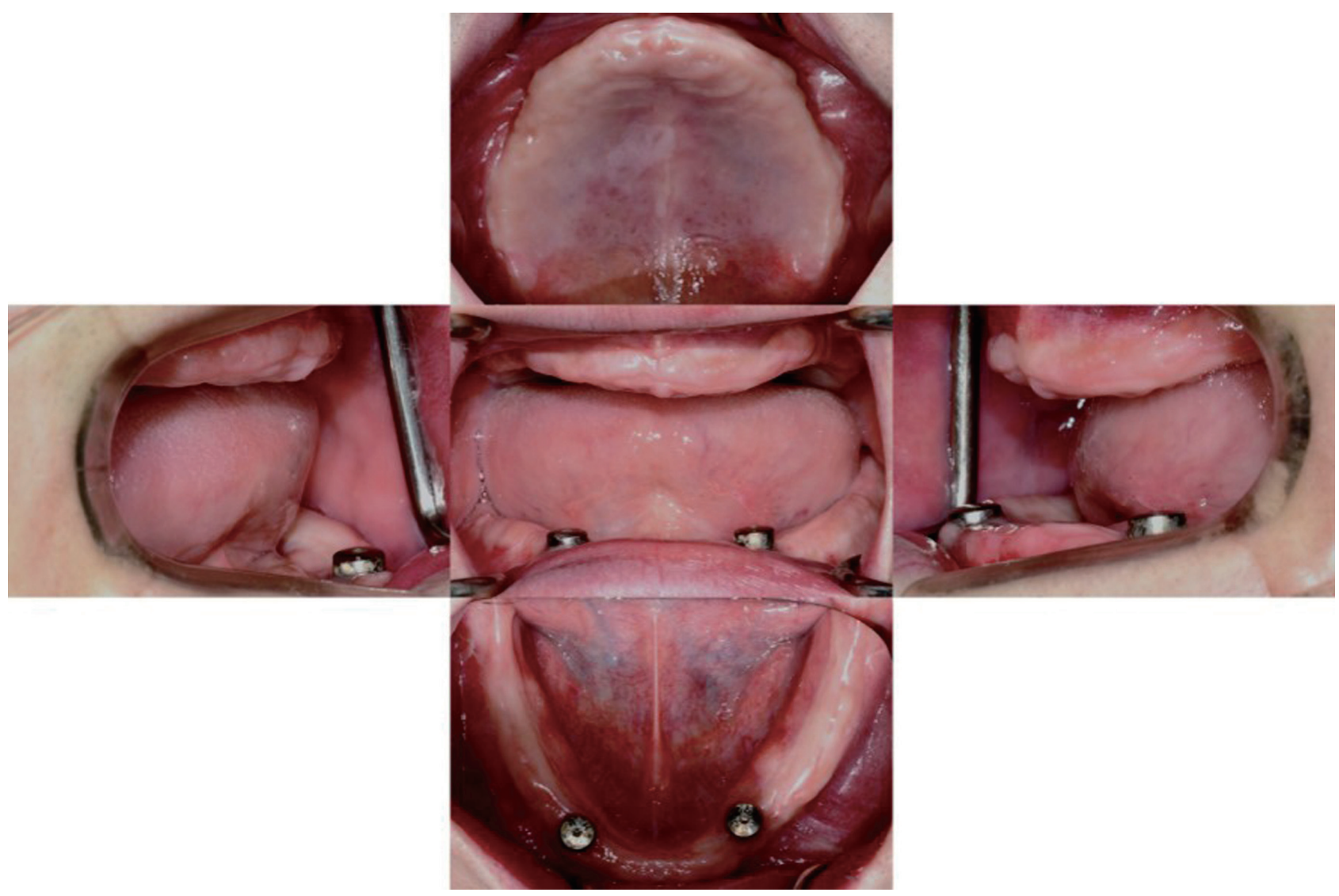

Fig. 3. Intraoral views after implants placement with healing abutment adaptation. This patient with Class III had relatively narrow inter-occlusal space.

3개월의 치유 기간을 가진 후, Osstell mentor (Osstell, Gothenburg, Sweden)를 이용하여 임플란트 안정성을 확인(ISQ = 72)하고 보철 수복을 진행하기로 하였다. 상하악 예비인상을 채득하여 진단모형을 제작 후 최종 인상용 트레이를 제작하였으며, 하악의 트레이는 후방 치조제의 지지를 얻기 위하여 협붕 부위의 완압은 하지 않았다. 상하악의 최종 인상채득은 모델링 콤파운드를 이용해서 변연 형성을 하였고, 하악의 경우 추가적으로 임플란트 지대주에 인상용 코핑을 연결하고 실리콘 계 열 인상재(EXADENTURE, GC, Tokyo, Japan)를 이용 하여 최종 인상을 채득하였다(Fig. 4). 하악은 인상 채득 후 인상용 코핑에 아날로그를 체결하여 주모형을 제작 하고 기록상과 교합제를 제작하였다. 교합제를 구강 내 에 시적하여 동공간선과 비익이주선을 기준으로 교합 평면을 설정하였고, 이를 바탕으로 중심위 기록을 채득 하여 안궁 이전을 시행하였다(Fig. 5). 인공 치아는 환자 의 성별, 안모, 피부색 등을 고려하여 전치부는 Endura

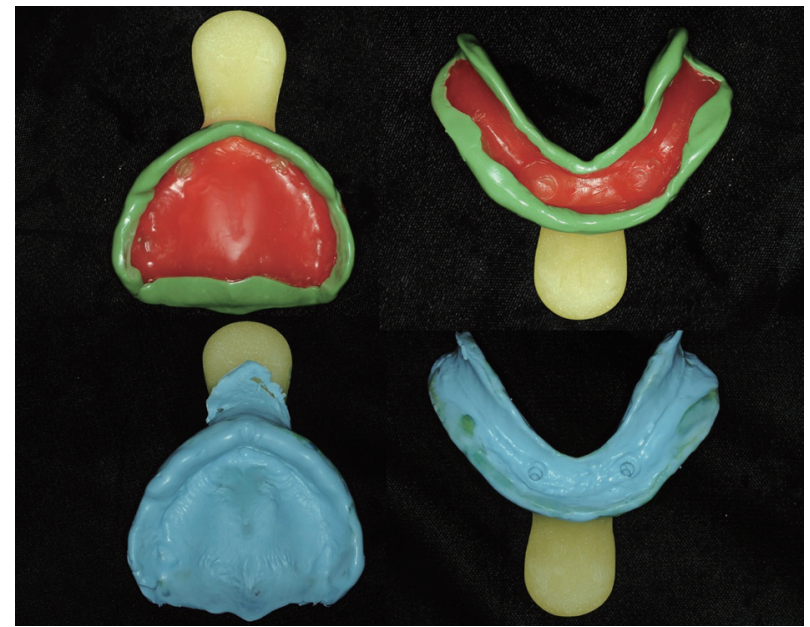

Fig. 4. Border molding and final impression.

(Shofu, Kyoto, Japan) HC4 Shade 106, 구치부는 Endura (Shofu) M30 Shade 66을 선택하였고, 총의치의 안정을 고려하여 양측성 균형교합을 부여하여 배열하였다. 


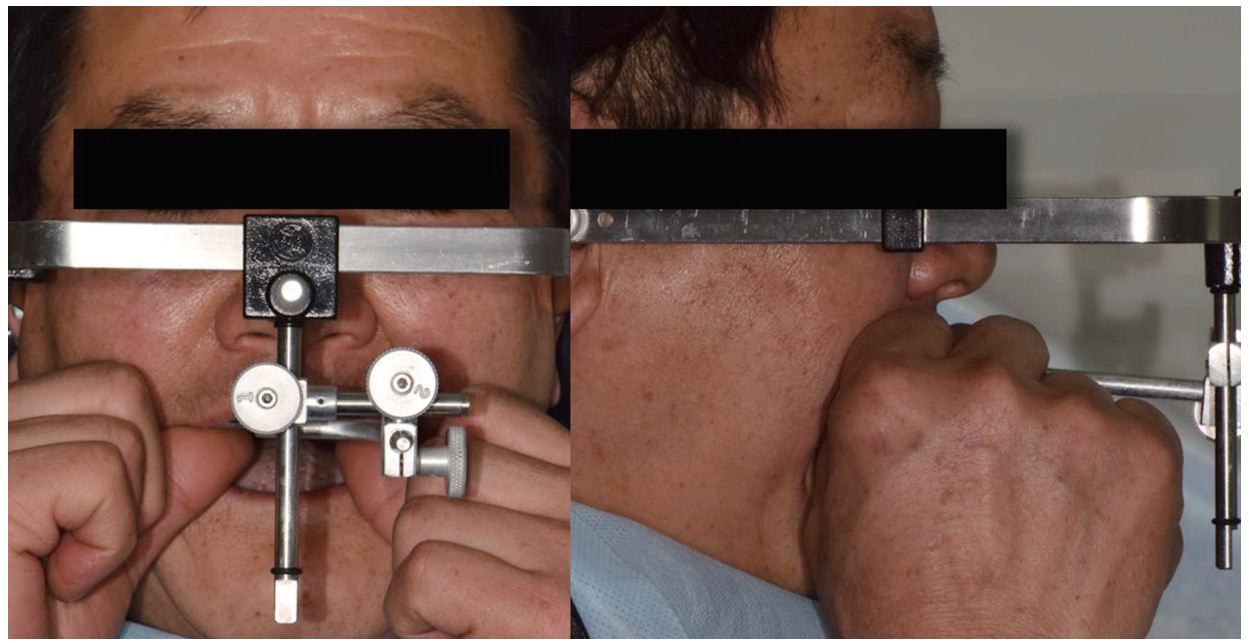

Fig. 5. Establishing the occlusal plane and taking the face-bow transfer. Frontal line was parallel to the inter-pupillary line, lateral line is parallel to Frankfort horizontal plane.

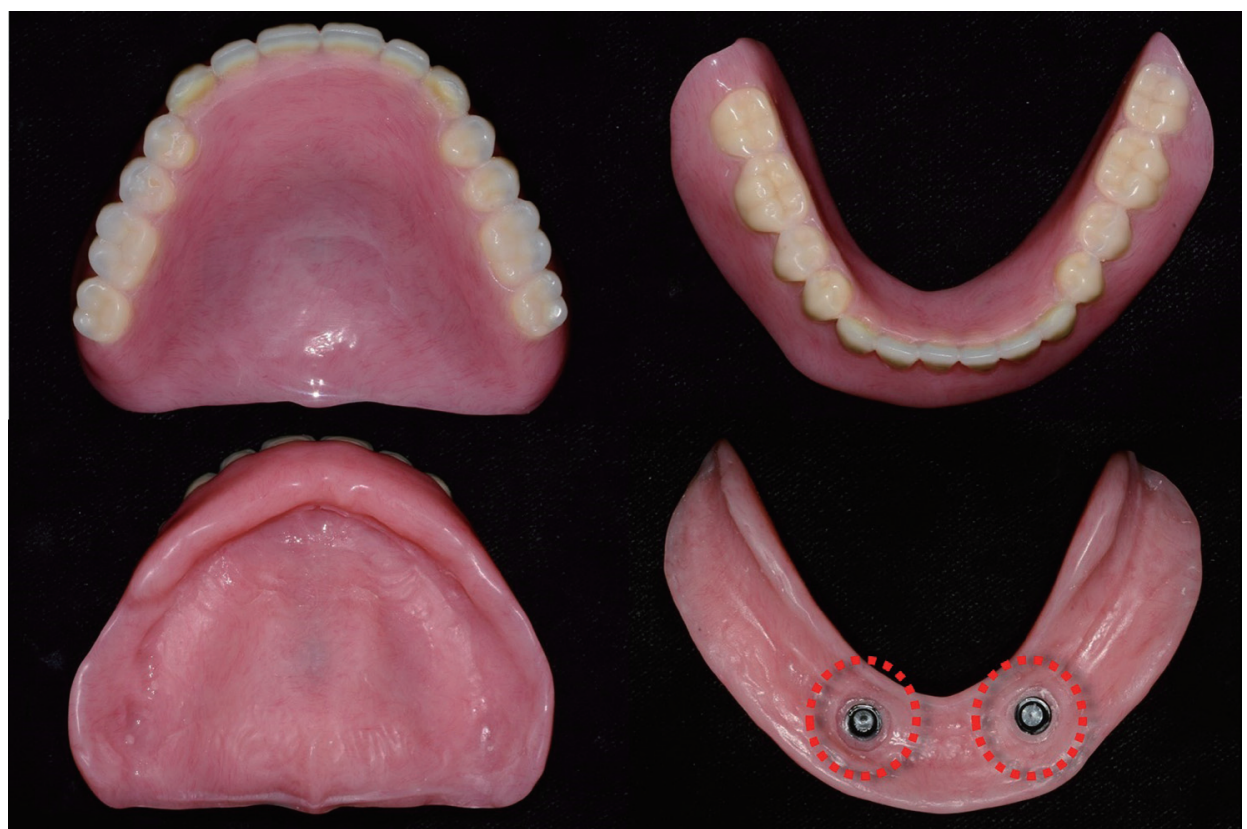

Fig. 6. Final dentures and installation of retention part of KERATOR attachment (Circles of dot indicate laboratory black male cap).

납의치를 시적 하여 수직고경, 교합평면, 수평·수직 피개량, 안모의 심미성을 평가하였다. 납의치를 매몰 후 레진 전입 및 온성을 시행하여 상하악 의치를 완성 하고 기공실 재부착 과정을 거쳐 교합조정을 시행하였 다. 제작된 의치는 구강 내에서 Fit checker (GC)를 이 용하여 의치상의 조직면 적합도와 변연 연장 정도를 평 가하고 양측성 균형교합을 확인하였다. 조정이 완료된
후, 어태치먼트의 부착을 위하여 구강 내 임플란트에 KERATOR ${ }^{\circledR}$ 어태치먼트를 체결하여 white block-out spacer를 위치시키고 메탈 하우징을 연결하였다. 그리고 의치의 내면에는 어태치먼트를 위한 공간을 형성한 후, 해당 부위에 아크릴릭 레진을 적용하여 구강 내에 안착 시켰다. 의치는 중합 완료 후에 white block-out spacer 를 제거하고 연마하여 의치를 완성하였다(Fig. 6,7). 


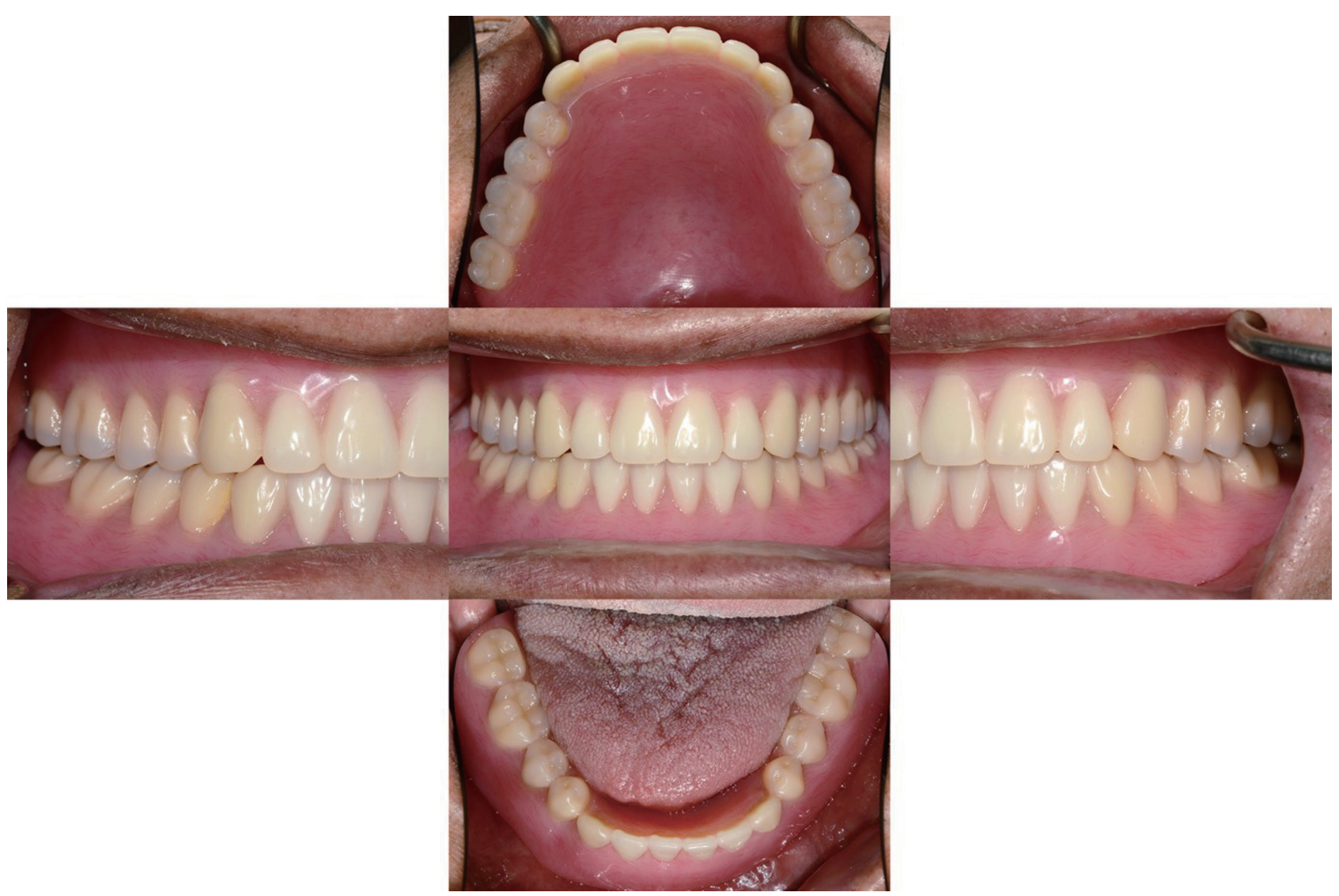

Fig. 7. Intraoral views with final dentures. All teeth contact opposite side evenly on centric relation.

두 번째 증례는 58세 남자 환자로서 틀니를 새로 만 들고 싶다는 주소로 임플란트 식립 후 본원에 내원하였 다. 구강 검사와 방사선 사진 검사에서 상하악 무치악으 로 전반적인 치조제 상실과 함께 하악 양측 견치 부위에 OSTEM TS III $\Phi 4.0 \times 10.0 \mathrm{~mm}$ (OSSTEM)의 임플란 트가 관찰되었다(Fig. 8). 임플란트의 식립 각도가 평행 하지 않았고(Fig. 9), 직업상 이유로 잦은 치과 내원이 어 렵다고 하여, 어태치먼트는 보상성이 우수하고 유지부
의 교체 없이 비교적 장기간 사용할 수 있는 EZ-LOCK ${ }^{\circledR}$ (TM Dental)을 선택하였다. EZ-LOCK ${ }^{\circledR}$ (TM Dental) 하우징의 부착 방법은 환자 구강 내에서 직접 장착시키 는 직접법과 기공실에서 장착시키는 간접법 모두 가능 하며, 진료 시간 단축과 기공 과정의 편의성을 위하여 간 접법을 이용하기로 결정하였다. 하우징은 주모형상에서 교합면과 최대한 평행하게 조절하여 부착하였으며, 통 상의 방법에 따라 의치 제작을 완료하였다(Fig. 10).

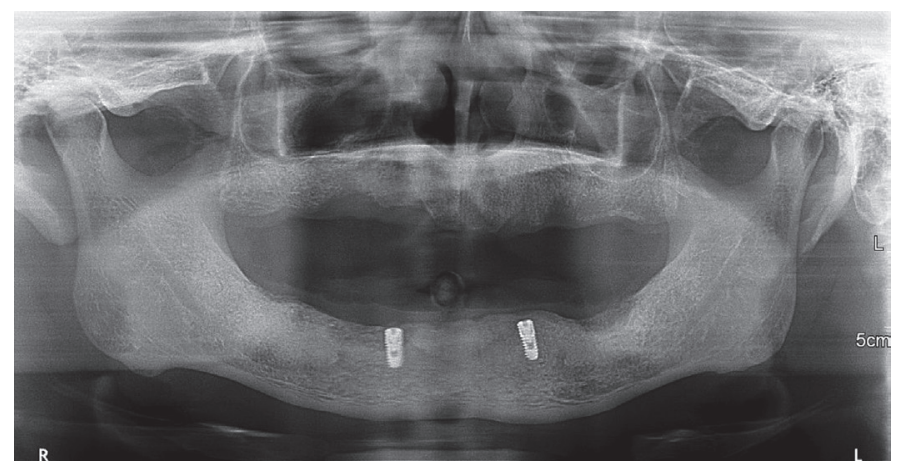

Fig. 8. Panoramic view of the 2 nd patient at implants installation on mandibular both canine area. 


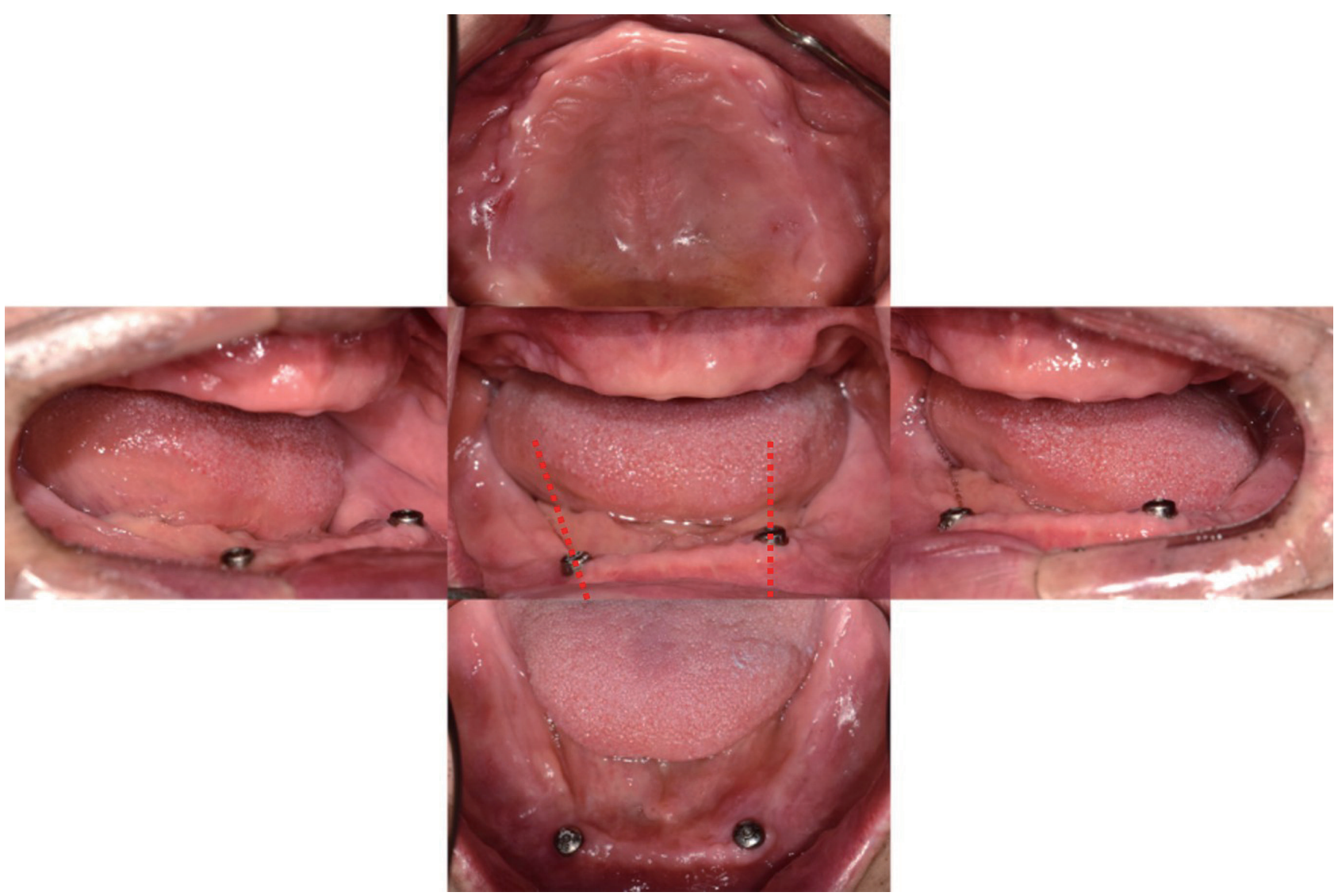

Fig. 9. Intraoral views after implant placement with healing abutment adaptation. It shows that direction of implants is non-parallel.

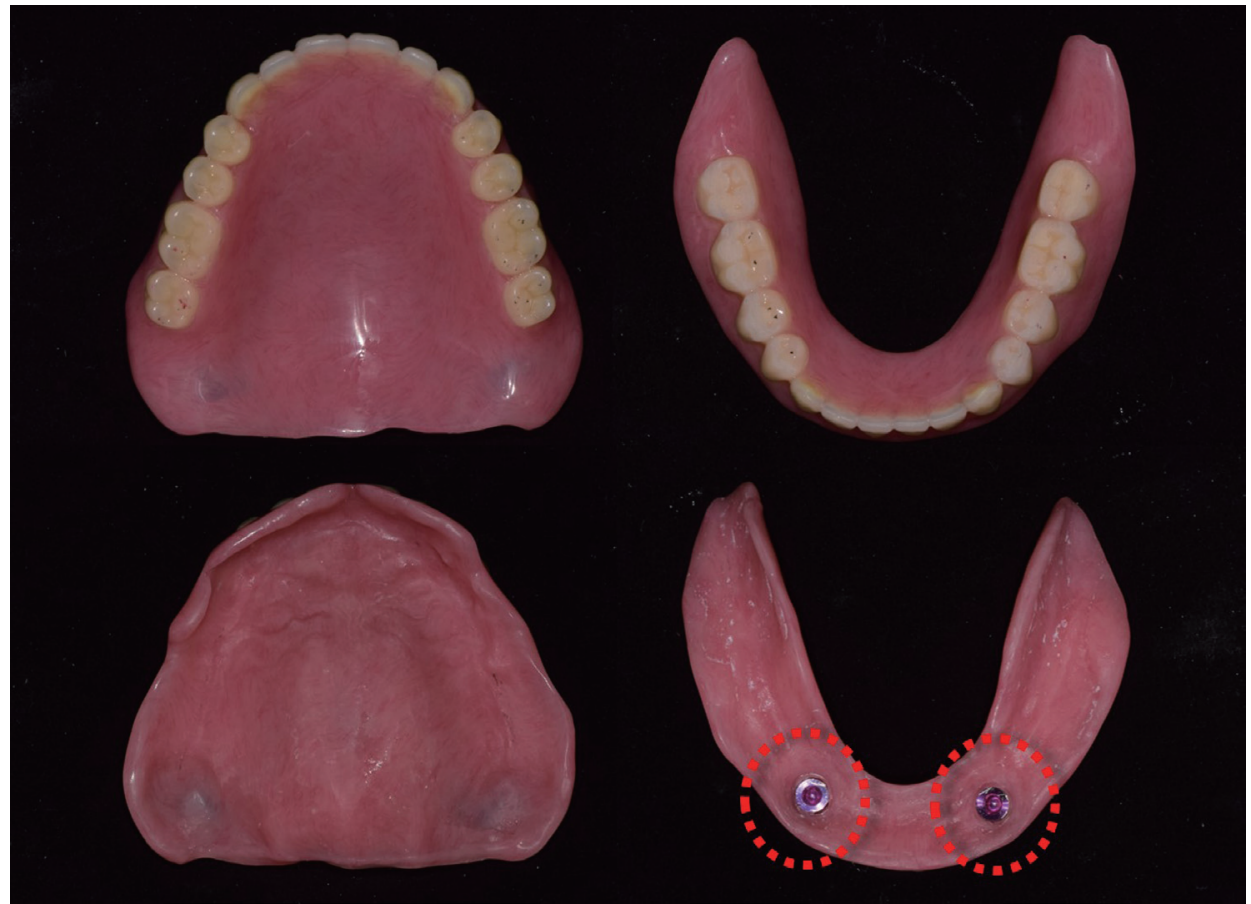

Fig. 10. Final dentures and installation of retention part of EZ-LOCK attachment on final denture (Circles of dot indicate EZ-LOCK metal housing). 
세 번째 증례는 50세 남자 환자로서 이가 흔들려서 틀 니를 하고 싶다는 주소로 본원에 내원하였다. 구강 검사 와 방사선 사진 검사에서 전반적인 골흡수 양상을 보였 으나, 하악의 이공 사이 견치 부위에는 임플란트를 식립 하기에 충분한 양의 골이 존재하였다. 오랜 기간 구치부 상실로 인하여 구치부 치조제가 낮고 좁으며, 날카로운 형태를 보였다. 이에 치조제 흡수가 심하고 좁은 치조제 를 갖는 경우에 사용될 수 있는 Dentium NR Line $\Phi 3.2$ $\times 9.0 \mathrm{~mm}$ (Dentium, Seoul, Korea)의 임플란트를 하악 양측 견치 부위에 식립 하였으며(Fig. 11, 12), 어태치먼 트는 Dentium NR Line 전용 magnet을 선택하였다. 통 상의 방법에 따라 의치를 제작한 후, 구강 내에서 임플 란트에 keeper를 체결하여 magnet을 연결하고, 제작된 의치의 임플란트 식립 부위에 vent hole을 형성하여 직 접법으로 부착하였다(Fig. 13).

위 증례의 환자들은 의치 사용 및 관리 방법과 구강위 생관리에 대해 교육한 후, 장착 24시간 후 재 내원 하도
록 하여 의치 조정을 시행하였으며, 주기적인 검진 및 내원의 필요성에 대하여 주지시켰다. 환자는 의치의 기 능과 심미성 모두에서 매우 만족하였으며 정기 점검 시 에도 불편감 없이 만족스럽게 사용하였다.

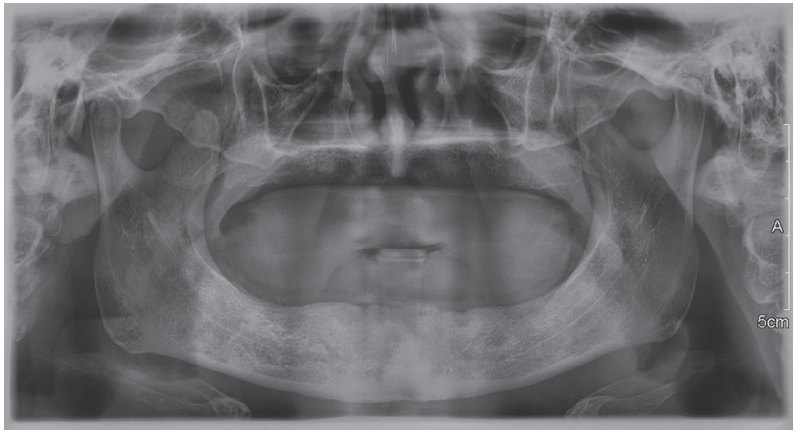

Fig. 11. Panoramic view of the 3rd patient with fully edentulous state on maxilla and mandible. As posterior teeth of mandible have been missing for a long time, severe residual ridge resorption was found.

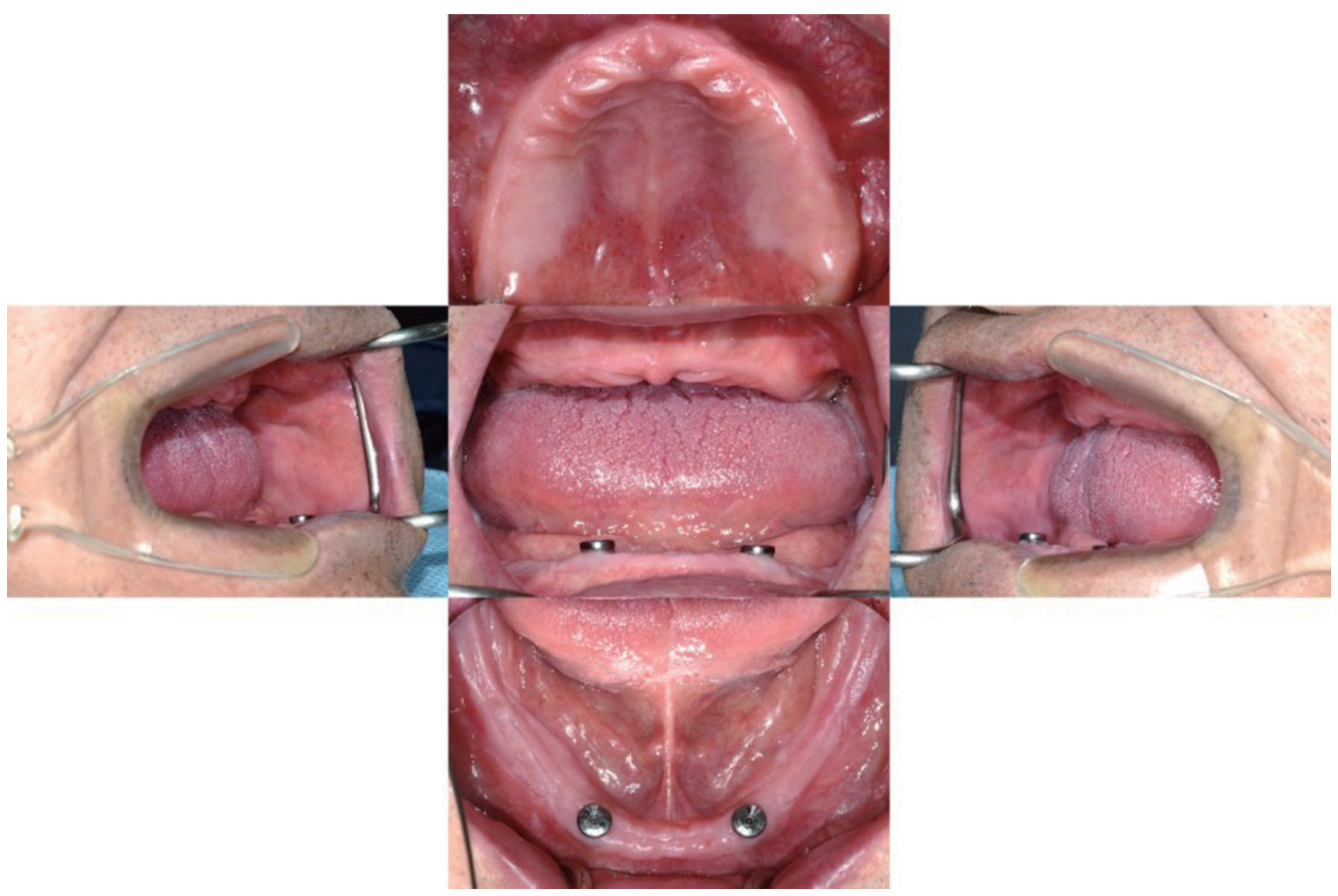

Fig. 12. Intraoral views after implant placement with healing abutment adaptation. It shows that severe resorption of alveolar ridge on mandibular posterior area. 


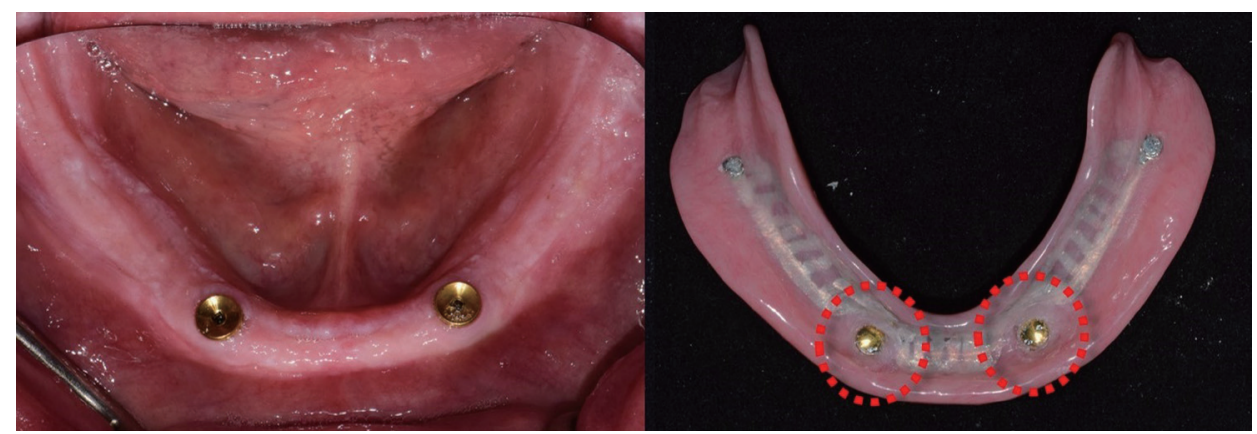

Fig. 13. Final dentures and installation of retention part of magnetic attachment on final denture (Circles of dot indicate magnetic attachment).

\section{고찰}

완전 무치악 환자에서 상악의 경우 넓은 지지 면적 과 변연 봉쇄를 이루기 용이하여 유지력을 확보하기가 쉽고, 통상적인 총의치에도 환자의 만족도가 높다. 반 면, 치조제 흡수가 심한 하악의 경우에는 통상적인 총의 치보다 유지력과 안정성이 우수한 임플란트 피개의치 는 무치악 환자에게 바람직한 치료법으로 평가되고 있 다. ${ }^{15,16}$ 위와 같은 이유로 본 증례에서는 완전 무치악 환 자에서 상악은 통상적인 총의치, 하악은 임플란트 피개 의치로 수복을 계획하였다.

임플란트 피개의치의 어태치먼트는 임플란트 식립 수, 위치, 식립 각도 등에 따라 적절히 선택하여야 한다. 본 증례에서는 악간 공간과 임플란트 식립 각도, 환자의 구강 상태를 고려하여 solitary type의 어태치먼트를 선 택하였다. 첫 번째 증례에서는 악간 공간이 좁고 충분한 유지력이 필요하여 $\mathrm{KERATOR}^{\circledR}$ 어태치먼트를, 두 번 째 증례에서는 임플란트 식립 각도의 보상이 필요하며 반영구적인 유지 장치가 필요하여 EZ-LOCK ${ }^{\circledR}$ 어태치 먼트를 선택하였다. 세 번째 증례의 Dentium사의 NR Line 임플란트는 치조제 흡수가 심하여 좁은 치조제를 갖는 경우에 사용된다. 식립 된 임플란트의 종류에 따 라 호환되는 어태치먼트를 확인하여야 하는 경우도 있 는데, NR Line 임플란트는 강한 sealing 효과를 위하여 임플란트 내부각도를 $10^{\circ}$ 로 부여하여 타사의 내부 각도 $11^{\circ}$ 와 다르기 때문에 다른 어태치먼트와 호환이 불가하 므로 Dentium 전용 magnet 어태치먼트를 선택하였다. Magnet 어태치먼트는 keeper와 자석 사이의 거리에 따
라 유지력의 급격한 저하가 보고되기 때문에,$^{13}$ 부착 과 정에서 술자의 세심한 주의가 요구된다.

어태치먼트를 의치 내면에 부착하는 방법으로는 환자 구강 내에서 직접 부착하는 직접법과 기공실에서 기공 과정을 통해 부착하는 간접법이 있다. 직접법은 술자의 숙련도가 요구되고 아크릴릭 레진에 의한 화학적 자극 과 구강 내 작업 시간이 증가할 수 있으나 간접법과 비 교하여 보다 정확한 위치에 어태치먼트를 장착할 수 있 으며, 간접법은 인상용 코핑과 아날로그 연결 등의 인상 과정에서 오차가 발생할 가능성이 있으나 아크릴릭 레 진에 의한 화학적 자극과 중합수축이 적으며 진료 시간 또한 단축시킬 수 있다. ${ }^{17}$ 술자는 임상 상황에 따라 적절 한 부착 방법으로 어태치먼트를 정확한 위치에 부착하 여 유지력을 증진시키고, 불필요한 어태치먼트의 마모 를 방지하여 내구성을 향상시킬 수 있도록 해야 할 것이 다.

임플란트 피개의치는 치료 이후의 적절한 유지 관리 가 실질적인 장기적 성공의 요인이다. 임플란트의 생물 학적, 기계적 실패를 막기 위해서는 임플란트 지대주에 가해지는 힘의 조절이 필요하며, 구강위생관리가 적절 히 행해지지 않을 경우 어태치먼트에 음식물이 침착 되 어 의치의 올바른 안착을 방해하거나 임플란트 주위의 염증을 유발할 수 있으므로, 의치 내면과 어태치먼트 주 위의 적절한 구강위생관리가 필수적일 것이다. 또한 제 작된 의치는 치조골 흡수에 따른 조직의 변형에 대한 적 절한 재이장과 교합 조정이 필요하다. ${ }^{8}$ 본 증례들은 주 기적인 검진과 경과 관찰을 통하여 모든 환자는 기능적, 심미적으로 만족할만한 결과를 얻었다. 


\section{결론}

본 증례들에서는 수종의 solitary type 어태치먼트를 이용한 임플란트 피개의치를 제작하였으며, 모든 환자 는 탈착에 어려움 없이 의치의 유지력과 심미에 만족하 였다. 이와 같이 치조제 흡수가 심한 무치악 환자에서 어태치먼트를 이용한 임플란트 피개의치 수복은 의치의 유지 및 지지의 측면에서 유리하고, 임플란트 고정성 수 복과 비교하여 저작력은 다소 떨어지지만, 치조제 흡수 가 심하여 구순의 지지가 필요한 경우에 보다 심미적이 며, 경제적 측면에서도 만족할만한 치료 방법으로 사료 된다.

\section{Acknowledgments}

이 논문은 2015년 단국대학교 교내연구비의 지원으로 연구되었음.

\section{Orcid}

Mid-Eum Park http://orcid.org/0000-0003-1991-274X

Soo-Yeon Shin http://orcid.org/0000-0001-6160-7277

\section{References}

1. Feine JS, Carlsson GE, Awad MA, Chehade A, Duncan WJ, Gizani S, Head T, Lund JP, MacEntee M, Mericske-Stern R, Mojon P, Morais J, Naert I, Payne AG, Penrod J, Stoker GT Jr, Tawse-Smith A, Taylor TD, Thomason JM, Thomson WM, Wismeijer D. The McGilll consensus statement on overdentures. Montreal, Quebec, Canada. May 2425, 2002. Int J Prosthodont 2002;15:413-4.

2. Rissin L, House JE, Manly RS, Kapur KK. Clinical comparison of masticatory performance and electromyographic activity of patients with complete dentures, overdentures and natural teeth. J Prosthet Dent 1978;39:508-11.

3. Kapur KK, Soman SD. Masticatory performance and efficiency in denture wearers. J Prosthet Dent 1964;4:687-94.

4. van Steenberghe D, Quirynen M, Callberson L, Demanet M. A prospective evaluation of the fate of 697 consecutive intraoral fixtures ad modum Brånemark in the rehabilitation of edentulism. J Head Neck Pathol 1987;6:53-8.

5. Närhi TO, Geertman ME, Hevinga M, Abdo H, Kalk W. Changes in the edentulous maxilla in persons wearing implant-retained mandibular overdentures. J Prosthet Dent 2000;84:43-9.

6. Kapur KK, Garrett NR, Hamada MO, Roumanas ED, Freymiller E, Han T, Diener RM, Levin S, Wong WK. Randomized clinical trial comparing the efficacy of mandibular implant supported overdentures and conventional dentures in diabetic patients. Part III: comparisons of patient satisfaction. J Prosthet Dent 1999;82:416-27.

7. Geertman ME, Van Waas MA, van't Hof MA, Kalk W. Denture satisfaction in a comparative study of implant-retained mandibular overdenture: a ramdomized clinical trial. Int J Oral Maxillofac Implant 1996;11:194-200.

8. Gotfredsen K, Holm B. Implant-supported mandibular overdentures retained with ball or bar attachments: a randomized prospective 5-year study. Int J Prosthodont 2000;13:125-30.

9. Bakke M, Holm B, Gotfredsen K. Masticatory function and patient satisfaction with implant supported mandibular overdentures: a prospective 5-year study. Int J Prosthdont 2002;15:575-81.

10. Thiel CP, Evans DB, Burnett RR. Combination syndrome associated with a mandibular implantsupported overdenture: a clinical report. J Prosthet Dent 1996;75:107-13.

11. Maxson BB, Powers MP, Scott RF. Prosthodontic considerations for the transmandibular implant. J Prosthet Dent 1990;63:554-8.

12. Barber HD, Scott RF, Maxon BB, Fonseca RJ. Evaluation of anterior maxillary alveolar ridge resorption when opposed by the transmandibular implant. J Oral Maxillofac Surg 1990;48:1283-7.

13. Schneider AL, Kurtzman GM. Bar overdentures utilizing the Locator attachment. Gen Dent 2001;49: 210-4.

14. Heckmann SM, Winter W, Meyer M, Weber HP, Wichmann MG. Overdenture attachment selection and the loading of implant and denture-bearing area. Part 2: a methodical study using five types of 
attachment. Clin Oral Implants Res 2001;12:640-7.

15. Sadowsky SJ. Mandibular implant-retained overdentures: a literature review. J Prosthet Dent 2001;86: 468-73.

16. Carlsson GE, Lindquist LW, Jemi T. Long-term marginal periimplant bone loss in edentulous patients. Int J Prosthodont 2000;13:295-302.

17. Nissan J, Oz-Ari B, Gross O, Ghelfan O, Chaushu
G. Long-term prosthetic aftercare of direct vs. indirect attachment incorporation techniques to mandibular implant-supported overdenture. Clin Oral Implants Res 2011;22:627-30.

18. Bilhan H, Geckili O, Mumcu E, Bilmenoglu C. Maintenance requirement associated with mandibular implant overdentures: clinical results after first year of service. J Oral Implantol 2011;37:697-704. 


\section{하악 무치악 환자에서 수종의 어태치먼트를 이용한 임플란트 피개의치 수복 증례}

\section{박믿음, 신수연*}

단국대학교 치과대학 치과보철학교실

무치악 환자에서는 치아가 상실되면서 주위 치조골의 개조와 흡수가 일어나고, 이에 따라 총의치의 유지력 감소, 저작 효율의 저하와 통증으로 인해 의치 사용에 어려움을 겪게 된다. 이를 개선하기 위해 하악에 2 - 4개의 임플란트를 식립 하고 어태치먼트에서 유지 또는 지지를 얻는 피개의치가 바람직한 치료 방법으로 고려되고 있다. 본 증례들은 하악 완 전 무치악 환자들을 악간 관계, 골흡수 정도, 안모지지 등을 평가하여 하악에 2 개의 임플란트 식립을 고려하고, 다양한 종류의 어태치먼트를 이용한 임플란트 피개의치 수복을 계획하여 치료하였다. 주기적인 경과 관찰 결과 심미적, 기능 적으로 만족할만한 결과를 얻었기에 이를 보고하는 바이다.

(구강회복응용과학지 2015;31 (3):242-52)

주요어: 임플란트; 하악 완전 무치악; 피개의치; 어태치먼트 